\title{
Beginning at the ends: telomeres and human disease [version
}

\section{1; peer review: 4 approved]}

\author{
Sharon A. Savage (i) \\ Clinical Genetics Branch, Division of Cancer Epidemiology and Genetics, National Cancer Institute, Bethesda, Maryland, USA
}

V1 First published: 01 May 2018, 7(F1000 Faculty Rev):524

https://doi.org/10.12688/f1000research.14068.1

Latest published: 01 May 2018, 7(F1000 Faculty Rev):524

https://doi.org/10.12688/f1000research.14068.1

\section{Abstract}

Studies of rare and common illnesses have led to remarkable progress in the understanding of the role of telomeres (nucleoprotein complexes at chromosome ends essential for chromosomal integrity) in human disease. Telomere biology disorders encompass a growing spectrum of conditions caused by rare pathogenic germline variants in genes encoding essential aspects of telomere function.

Dyskeratosis congenita, a disorder at the severe end of this spectrum, typically presents in childhood with the classic triad of abnormal skin pigmentation, nail dystrophy, and oral leukoplakia, accompanied by a very high risk of bone marrow failure, cancer, pulmonary fibrosis, and other medical problems. In contrast, the less severe end of the telomere biology disorder spectrum consists of middle-age or older adults with just one feature typically seen in dyskeratosis congenita, such as pulmonary fibrosis or bone marrow failure. In the common disease realm, large-scale molecular epidemiology studies have discovered novel associations between illnesses, such as cancer, heart disease, and mental health, and both telomere length and common genetic variants in telomere biology genes. This review highlights recent findings of telomere biology in human disease from both the rare and common disease perspectives. Multi-disciplinary collaborations between clinicians, basic scientists, and epidemiologist are essential as we seek to incorporate new telomere biology discoveries to improve health outcomes.

\section{Keywords}

telomere, dyskeratosis congenita, telomere biology disorder, cancer, Coats plus, Hoyeraal Hreidsarsson syndrome, epidemiology

\section{Open Peer Review}

Approval Status

\begin{tabular}{|c|c|c|c|c|}
\hline & 1 & 2 & 3 & 4 \\
\hline $\begin{array}{l}\text { version } 1 \\
01 \text { May } 2018\end{array}$ & $\checkmark$ & $\checkmark$ & $\checkmark$ & $\checkmark$ \\
\hline
\end{tabular}

Faculty Reviews are review articles written by the prestigious Members of Faculty Opinions. The articles are commissioned and peer reviewed before publication to ensure that the final, published version is comprehensive and accessible. The reviewers who approved the final version are listed with their names and affiliations.

1. Dirk Hockemeyer, University of California, Berkeley, Berkeley, USA

2. Tracy Bryan, University of Sydney, Sydney, Australia

3. Steven E. Artandi, Stanford University School of Medicine, Stanford, USA

Stanford University School of Medicine,

Stanford, USA

Stanford University School of Medicine, Stanford, USA

4. Fadi Charchar, Federation University, Ballarat, Australia

Any comments on the article can be found at the 
end of the article.

Corresponding author: Sharon A. Savage (savagesh@mail.nih.gov)

Author roles: Savage SA: Conceptualization, Data Curation, Funding Acquisition, Investigation, Project Administration, Writing - Original Draft Preparation, Writing - Review \& Editing

Competing interests: No competing interests were disclosed.

Grant information: This work was supported by the intramural research program of the Division of Cancer Epidemiology and Genetics, National Cancer Institute, National Institutes of Health.

The funders had no role in study design, data collection and analysis, decision to publish, or preparation of the manuscript.

Copyright: $\odot 2018$ Savage SA. This is an open access article distributed under the terms of the Creative Commons Attribution License, which permits unrestricted use, distribution, and reproduction in any medium, provided the original work is properly cited. The author(s) is/are employees of the US Government and therefore domestic copyright protection in USA does not apply to this work. The work may be protected under the copyright laws of other jurisdictions when used in those jurisdictions.

How to cite this article: Savage SA. Beginning at the ends: telomeres and human disease [version 1; peer review: 4 approved] F1000Research 2018, 7(F1000 Faculty Rev):524 https://doi.org/10.12688/f1000research.14068.1

First published: 01 May 2018, 7(F1000 Faculty Rev):524 https://doi.org/10.12688/f1000research.14068.1 


\section{Introduction}

Telomeres are the nucleoprotein complex at chromosome ends with essential roles in maintaining chromosomal integrity. They shorten with each cell division because of incomplete replication of the $3^{\prime}$ ends of DNA and thus are markers of cellular aging. Over the last decade, there has been remarkable growth in the breadth and depth of understanding the multiple roles of telomere biology in human disease. At one end of the spectrum, very rare pathogenic germline genetic variants in telomere biology genes cause exceedingly short telomeres, resulting in dyskeratosis congenita (DC) and its related telomere biology disorders. The other end of the spectrum consists of large-scale population-based studies seeking to determine associations between telomere length human disease, environmental exposures, or common genetic variants as well as the interactions between these factors.

The complexity of these interactions requires an integrated understanding of telomere basic science, clinical medicine, and epidemiology (Figure 1). Each of these topics is worthy of an in-depth critical review beyond the scope of this article. Instead, I will highlight some key findings and methodologic considerations and discuss where additional research is needed to aid in understanding the contribution of telomere biology to both rare and common human diseases.

\section{Dyskeratosis congenita - a direct connection between germline telomere biology and human disease}

DC was first described in a 1906 case report of males with the mucocutaneous triad of abnormal skin pigmentation, nail dystrophy, and oral leukoplakia (Figure 2) ${ }^{1}$. Additional similar cases were reported, including the first female case in $1963^{2-5}$. Patients with DC also have very high rates of bone marrow failure; stenosis of the esophagus, urethra, or lacrimal ducts (or a combination of these); head and neck squamous cell carcinoma (HNSCC); myelodysplastic syndrome (MDS); acute myeloid leukemia (AML); pulmonary fibrosis; liver disease; avascular necrosis of the hips; and other medical problems (Table 1$)^{6}$. $\mathrm{DC}$ is inherited in $\mathrm{X}$-linked recessive, autosomal dominant, or autosomal recessive patterns.

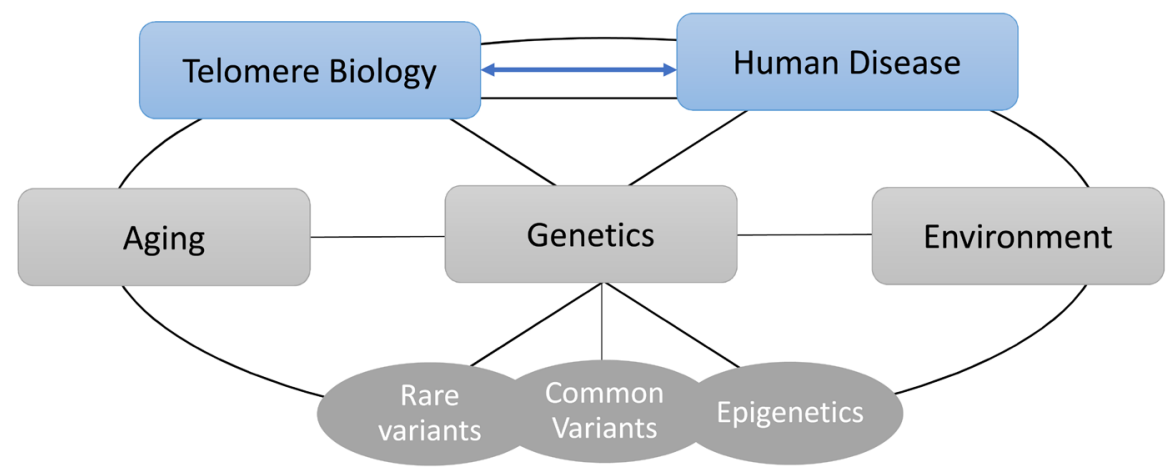

Figure 1. Factors associated with human disease are integrally connected to telomere biology. This schematic illustrates the complex relationships between telomere biology, disease, aging, genetics, and environmental exposures, all of which should be considered in studies of telomeres and human disease.
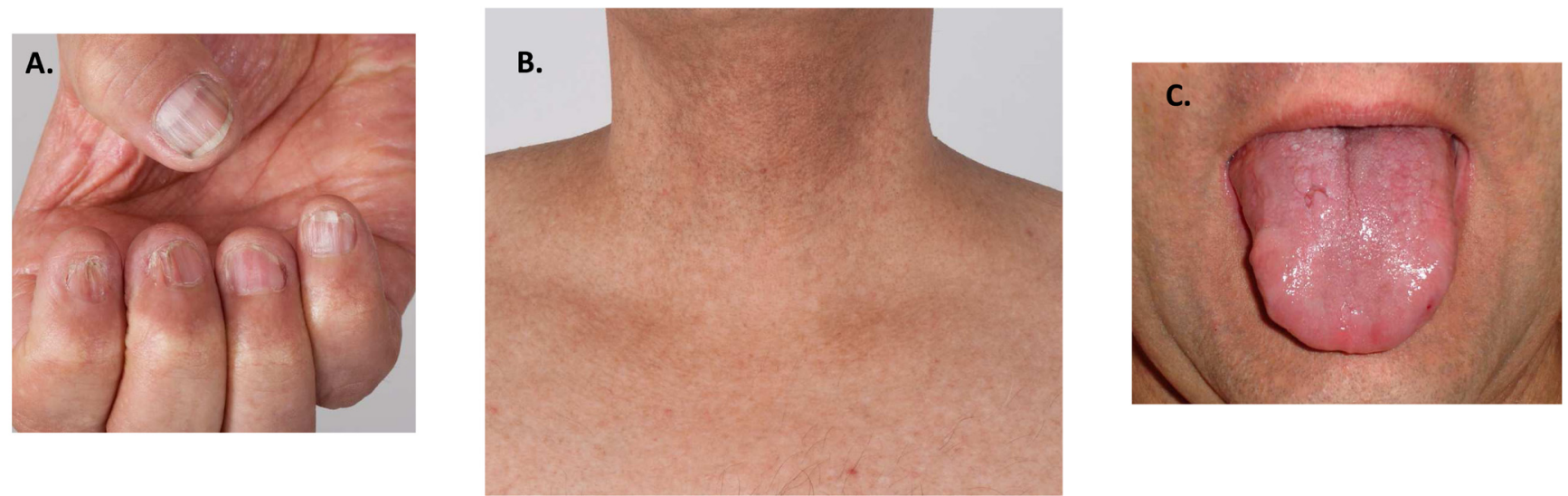

Figure 2. Mucocutaneous features of dyskeratosis congenita of an adult male whose disease is due to a DKC1 mutation. (A) Dystrophic and ridged fingernails. (B) Hyper- and hypo-pigmented skin of neck and upper chest. (C) Irregular leukoplakia of the tongue. 
Table 1. Clinical features of telomere biology disorders.

\begin{tabular}{|c|c|}
\hline Disorder & Key clinical features ${ }^{a}$ \\
\hline Dyskeratosis congenita (DC) & $\begin{array}{l}\text { Mucocutaneous triad of nail dysplasia, abnormal skin pigmentation (hyper/hypopigmented, lacy, } \\
\text { reticular pigmentation), and oral leukoplakia. BMF, PF, PAVM, liver disease, avascular necrosis } \\
\text { of hips or shoulders (or both), urethral stenosis, lacrimal duct stenosis, esophageal stenosis, } \\
\text { HNSCC, MDS, AML, and/or developmental delay. Traditional diagnosis of DC: classic triad or one } \\
\text { of the triad, BMF, and two other findings }{ }^{7} \text {. }\end{array}$ \\
\hline Revesz syndrome & $\begin{array}{l}\text { Features of DC plus bilateral exudative retinopathy. Intracranial calcifications and developmental } \\
\text { delay also reported. }\end{array}$ \\
\hline $\begin{array}{l}\text { Hoyeraal Hreidarsson } \\
\text { syndrome }\end{array}$ & $\begin{array}{l}\text { Features of DC plus cerebellar hypoplasia. Immunodeficiency has been reported as presenting } \\
\text { problem. }\end{array}$ \\
\hline Coats plus & $\begin{array}{l}\text { Bilateral retinopathy, intracranial calcifications, leukodystrophy, anemia, osteopenia, and poor } \\
\text { bone healing }\end{array}$ \\
\hline DC-like & $\begin{array}{l}\text { BMF, AA, MDS, or PF occurring in presence of at least one other DC-associated feature or family } \\
\text { history suspicious of DC }\end{array}$ \\
\hline Aplastic anemia & $\begin{array}{l}\text { Progressive multi-lineage cytopenias, non-immune mediated. May occur in the absence of DC- } \\
\text { associated features. }\end{array}$ \\
\hline Myelodysplastic syndrome & $\begin{array}{l}\text { Cytopenias with cellular dysplasia or clonal chromosomal translocations or both. May occur in the } \\
\text { absence of DC-associated features. }\end{array}$ \\
\hline Acute myeloid leukemia & May progress from MDS or aplastic anemia. May occur in the absence of DC-associated features. \\
\hline Pulmonary fibrosis & May occur in the absence of DC-associated features. \\
\hline Liver fibrosis & Non-alcoholic, non-infectious liver disease. May occur in the absence of DC-associated features. \\
\hline Familial melanoma & Multiple family members with melanoma, often early age at onset \\
\hline $\begin{array}{l}\text { Familial lymphoproliferative } \\
\text { disease }\end{array}$ & Multiple-affected family members with chronic lymphocytic leukemia, or non-Hodgkin lymphoma \\
\hline Li-Fraumeni-like syndrome & Cancer family history notable for angiosarcoma and other cancers \\
\hline
\end{tabular}

The first DC genetic locus was mapped to Xq28 in 1996 and specifically to mutations in dyskerin (encoded by $D K C 1$ ) in $1999^{8-10}$. The seminal work by Mitchell and Collins was the first to show a connection between telomere biology and human disease through aberrant dyskerin function and the resultant very short telomeres now well known in patients with $\mathrm{DC}^{11}$. Currently, DKCl mutations account for about $25 \%$ of classic DC cases. A combination of candidate gene sequencing, genetic linkage studies, and whole exome sequencing occurring over the last 15 years has since identified at least 14 telomere biology genes associated with DC or DC-like phenotypes: telomerase holoenzyme complex (DKC1, TERC, TERT, NOP10, and NHP2), shelterin telomere protection complex (ACD, TINF2, and $P O T 1$ ), telomere capping proteins (CTC1 and STN1), and other proteins that directly or indirectly interact with these key cellular processes (RTEL1, NAF1, WRAP53, and PARN) (Figure 3 and Table 2) (reviewed in 6).

The germline mutations in DC-associated telomere biology genes result in very short telomere lengths for age (Figure 4). This knowledge made it possible to develop a diagnostic test for DC, flow cytometry with fluorescent in situ hybridization (flow FISH), in leukocyte subsets ${ }^{12}$. Lymphocyte telomeres less than the first percentile for age are more than $95 \%$ sensitive and specific for differentiating patients with DC from their unaffected relatives or patients with other inherited bone marrow failure syndromes ${ }^{13,14}$. In addition to aiding diagnosis, using telomeres less than the first percentile for age has greatly added in discovering the genetic causes of $\mathrm{DC}^{15}$.

\section{Telomere biology disorders - many names connected by pathophysiology}

The discovery of the multiple genetic causes and modes of inheritance has led to a growing appreciation that there is a wide range of clinical phenotypes associated with mutations in telomere biology genes. This started with the identification of TERT and TERC mutations in patients with apparently isolated aplastic anemia or pulmonary fibrosis ${ }^{16-18}$. As defined above, classic DC is a complex multi-system disorder, but variable penetrance and expressivity of the clinical manifestations have identified a growing number of patients with one or a few features of DC as well as germline mutations in telomere biology genes and short telomeres (Table 1 and Table 2). This spectrum of illnesses has been termed telomeropathy, short telomere syndromes, or telomere biology disorders (TBDs) ${ }^{6,19-22}$. The last of these, TBD, was proposed and is favored because it is more descriptive and reflective of the underlying biology that unites these disorders ${ }^{6,22}$. 


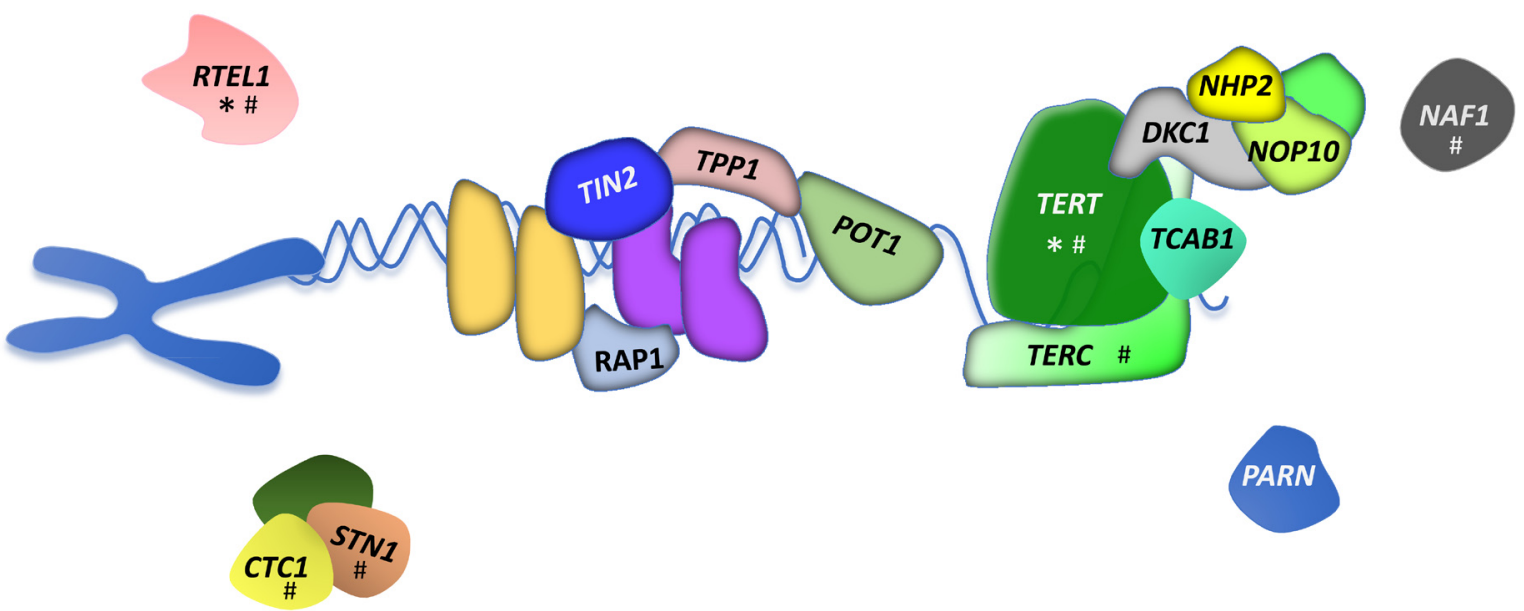

Figure 3. Proteins encoding key components of telomere biology associated with disease. Protein names are noted in the figure. Associated disease and mode(s) of inheritance are shown in Table 1. The asterisk indicates proteins encoded by genes with single-nucleotide polymorphisms associated with cancer. The pound sign indicates proteins encoded by genes with single-nucleotide polymorphisms associated with telomere length.

Table 2. Germline genetics of telomere biology disorders.

\begin{tabular}{|c|c|c|c|c|}
\hline Gene & Protein name(s) & Disorder(s) & $\begin{array}{l}\text { Mode of } \\
\text { inheritance }\end{array}$ & $\begin{array}{l}\text { Year gene first associated } \\
\text { with any disease, relevant } \\
\text { reference(s) }\end{array}$ \\
\hline$D K C 1$ & DKC1, dyskerin & $\mathrm{DC}, \mathrm{HH}$ & $X L R$ & $1998^{23}$ \\
\hline TERC & $\begin{array}{l}\text { hTr, telomerase RNA component } \\
\text { (encodes an RNA) }\end{array}$ & $D C, A A, P F$ & $A D$ & $2001^{16,18,24}$ \\
\hline \multirow[t]{2}{*}{ TERT } & \multirow[t]{2}{*}{ TERT, telomerase } & $\begin{array}{l}\text { DC, AA, MDS, AML, } \\
\text { PF, LD, FM }\end{array}$ & $A D$ & \multirow[t]{2}{*}{$2005^{16,17,25-27}$} \\
\hline & & $\mathrm{HH}$ & AR & \\
\hline NOP10 & $\begin{array}{l}\text { NOP10, NOLA3, nucleolar protein } \\
\text { family A, member } 3\end{array}$ & DC & AR & $2007^{28}$ \\
\hline NHP2 & $\begin{array}{l}\text { NHP2, NOLA2 nucleolar protein } \\
\text { family A, member } 2\end{array}$ & DC & AR & $2008^{29}$ \\
\hline TINF2 & $\begin{array}{l}\text { TIN2, TERF1 (TRF1)-interacting } \\
\text { nuclear factor } 2\end{array}$ & $\mathrm{DC}, \mathrm{HH}, \mathrm{RS}$ & $A D$ & $2008^{15}$ \\
\hline WRAP53 & $\begin{array}{l}\text { TCAB1, telomere cajal body } \\
\text { associated protein } 1\end{array}$ & $\mathrm{DC}, \mathrm{HH}$ & AR & $2011^{30,31}$ \\
\hline CTC1 & $\begin{array}{l}\text { CTC1, conserved telomere } \\
\text { maintenance component } 1\end{array}$ & CP, DC & AR & $2012^{32-34}$ \\
\hline \multirow[t]{2}{*}{ RTEL 1} & \multirow{2}{*}{$\begin{array}{l}\text { RTEL1, regulator of telomere } \\
\text { elongation helicase } 1\end{array}$} & PF, AA & $A D$ & \multirow[t]{2}{*}{$2013^{35-40}$} \\
\hline & & $\mathrm{DC}, \mathrm{HH}$ & AR & \\
\hline TERF2IP & RAP1, TERF2-interacting protein & FM & $A D$ & $2015^{41}$ \\
\hline \multirow[t]{2}{*}{ PARN } & \multirow{2}{*}{$\begin{array}{l}\text { PARN, poly(A)-specific } \\
\text { ribonuclease }\end{array}$} & PF & $A D$ & \multirow[t]{2}{*}{$2015^{42-45}$} \\
\hline & & $\mathrm{DC}, \mathrm{HH}$ & AR & \\
\hline \multirow[t]{2}{*}{$A C D$} & \multirow[t]{2}{*}{ TPP1, telomere protection protein 1} & AA, FM, FLPD & $A D$ & $2014^{41,46,47}$ \\
\hline & & $\mathrm{HH}$ & $A R$ & $2016^{48}$ \\
\hline STN1 & STN1, CST-complex subunit & $\mathrm{CP}$ & AR & $2016^{49}$ \\
\hline \multirow[t]{2}{*}{ POT1 } & \multirow[t]{2}{*}{ POT1, protection of telomeres 1} & FM, FLPD, LFL & $A D$ & $2014^{47,50-52}$ \\
\hline & & $\mathrm{CP}$ & AR & $2016^{53}$ \\
\hline NAF1 & $\begin{array}{l}\text { NAF1, nuclear assembly factor } 1 \\
\text { ribonucleoprotein }\end{array}$ & PF & $A D$ & $2016^{54}$ \\
\hline
\end{tabular}

AA, aplastic anemia; AD, autosomal dominant; AML, acute myeloid leukemia; AR, autosomal recessive; CP, Coats plus; DC, dyskeratosis congenita; FLPD, familial lymphoproliferative disease; FM, familial melanoma; HH, HoyeraalHreidarsson syndrome; LD, liver disease; LFL, Li-Fraumeni-like syndrome; MDS, myelodysplastic syndrome; PF, pulmonary fibrosis; RS, Revesz syndrome; XLR, X-linked recessive. 


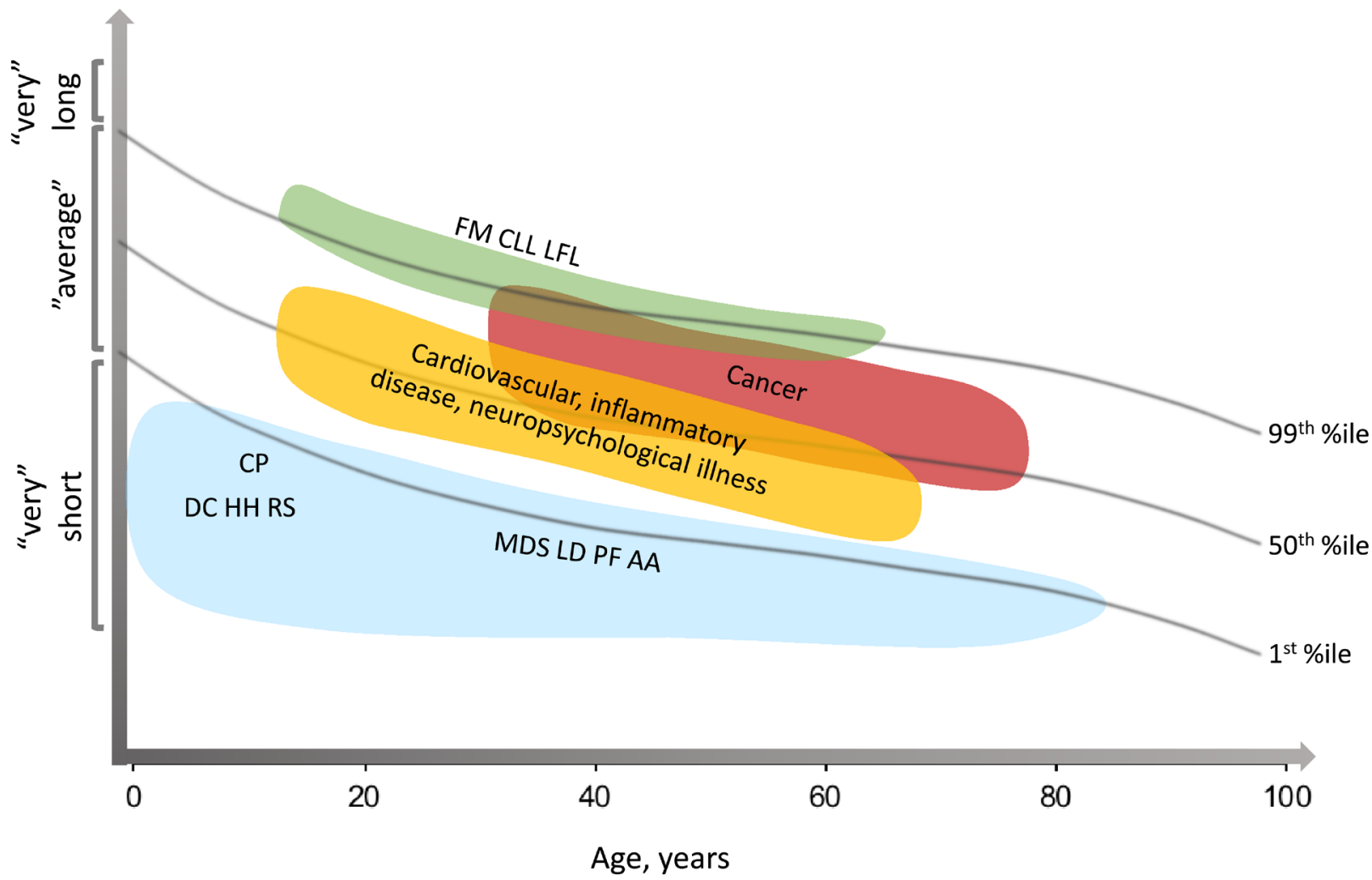

Figure 4. Schematic representation of the connections between age, telomere length, and human disease. Clinically significant telomeres associated with telomere biology disorders are generally at or below the first percentile for age (blue shape). Many association studies of telomere length and human phenotypes, including cancer, have identified statistically significant, but perhaps not clinically significant, differences in telomere length between cases and controls (represented by yellow and red). Some studies have identified rare families with germline mutations in components of the shelterin telomere protection complex as associated with longer telomeres (green shape). AA, aplastic anemia; CLL, chronic lymphocytic leukemia; CP, Coats plus; DC, dyskeratosis congenita; FM, familial melanoma; HH, Hoyeraal Hreidarsson syndrome; LD, liver disease; LFL, Li-Fraumeni-like syndrome; MDS, myelodysplastic syndrome; PF, pulmonary fibrosis; RS, Revesz syndrome.

The most complex TBDs are those disorders presenting very early in childhood, namely Hoyeraal Hreidarsson syndrome $(\mathrm{HH})$, Revesz syndrome (RS), and Coats plus ${ }^{6,55-60}$. In addition to having features of DC, patients with $\mathrm{HH}$ have cerebellar hypoplasia and immunodeficiency, whereas those with RS also have bilateral exudative retinopathy. Coats plus, a disorder characterized by retinal and gastrointestinal vascular abnormalities, poor bone healing, leukodystrophy, and cerebellar calcifications, joined the TBD spectrum when its primary cause was identified as autosomal recessive $C T C 1$ mutations $^{32,33,59}$.

The other end of the clinical spectrum includes patients with middle or later age at onset of pulmonary fibrosis, liver disease, or bone marrow failure and heterozygous germline mutations in NAF1, TERT, TERC, PARN, or RTEL1 17,18,42,61. Additionally, it is important to note that most patients do not have all of the DC-associated medical complications. The mucocutaneous triad is diagnostic but varies with the age of onset and is usually progressive over time. Many patients, even members of the same family, may present with just one feature but develop more over time because of variable penetrance and expressivity of germline telomere biology defects.

There is also a growing role of mutations in the shelterin complex and cancer-prone families without DC-related clinical manifestations. Heterozygous rare, pathogenic variants in POT1 resulting in longer telomeres have been reported in familial melanoma, familial chronic lymphocytic leukemia (CLL), and a Li-Fraumeni-like syndrome family ${ }^{50-52}$. POT1 somatic mutations in CLL have also been associated with CLL outcomes ${ }^{62-65}$. Familial melanoma has also been associated with germline mutations in ACD (TPP1) and TERF2IP (RAP1) ${ }^{41}$. These studies suggest an interesting dichotomy in clinical phenotypes resulting from long versus short telomeres.

\section{Telomeres and cancer}

Telomeres are closely connected to cancer biology because of the role they play in chromosomal stability. There is a 
detailed body of work in this realm and only a few of the key features will be highlighted herein as they have been reviewed in detail elsewhere ${ }^{66-73}$.

The primary hypotheses connecting telomeres and cancer are based on the fact that telomeres shorten with each cell divi$\operatorname{sion}^{74}$. In general, cellular senescence or apoptosis is triggered when telomeres reach a critically short state. It likely takes just one critically short telomere on one chromosome arm to trigger these events as suggested in a TERC mouse model by Hemann et $a{ }^{75}$. A cellular survival advantage is gained through bypassing apoptosis or senescence through the upregulation of telomerase, inactivation of TP53 or RB or both, initiation of alternative lengthening of telomeres (ALT), and other key biological pathways ${ }^{76-80}$. The continued division of cells originally destined for death is hypothesized to lead to continued accumulation of mutations, and sticky chromosome ends due to abnormal telomeres can contribute to chromosomal aneuploidy. Unchecked cellular growth can occur if these genetic aberrations result in a growth advantage.

Activating somatic mutations in the TERT promoter have been described in melanoma, bladder, thyroid, and some central nervous system cancers ${ }^{81-83}$. These somatic mutations in the TERT promoter result in increased telomerase expression and suggest that this activation could convey a growth advantage as cancer cells continue to divide despite the presence of aberrant telomeres.

Patients with DC/TBD have significantly increased risks of MDS, AML, HNSCC, and other malignancies ${ }^{84-86}$. The 2017 update of cancer in the National Cancer Institute Inherited Bone Marrow Failure Syndrome cohort reported that cancer in patients with DC occurs at an approximately four fold higher incidence and a younger age than the general population ${ }^{87}$. MDS and AML occurred at 578- and 24-fold greater incidence, respectively, than the general population. There was also an excess of solid cancers in patients with DC with observed/expected ratios of 74 for any HNSCC and 216 for tongue HNSCC ${ }^{87}$. The mechanisms by which cancer develops in patients with DC/TBDs is unknown and represents an important research opportunity.
Cells of patients with TBD already have a "first hit" in a key component of telomere biology. Studies of the next steps in carcinogenesis in patient-derived cells could lead to important insights into the carcinogenic process.

\section{The advent of telomere molecular epidemiology}

Telomere molecular epidemiology has emerged with the development of high-throughput telomere length measurement methods, genome-wide genotyping platforms, and keen interest in the role of telomere biology in human disease ${ }^{88,89}$. These large, often population-based studies seek to determine (1) whether telomere length is associated with disease, (2) whether common genetic variants (that is, single-nucleotide polymorphisms, or SNPs) are associated with telomere length, (3) the degree to which SNPs contribute to telomere biology, and (4) interactions between telomere length, SNPs, and disease or phenotypes (Figure 1 and Table 3). Although a great deal of excitement has been generated by these studies, it is important to point out that differences in telomere length between cases and controls in large population-based studies may be statistically significant but not clinically relevant. "Short telomeres" in a large case-control or cohort study are still within the clinically "normal" range and not nearly as short as telomeres of patients with TBDs (Figure 4).

Robust and accurate telomere length measurement is at the crux of all telomere length association studies. Blood or buccal cell DNA telomere length has been evaluated in a wide array of association studies, including cancer, cardiovascular disease, mental health, inflammatory diseases, environmental exposures, and many other settings. There are numerous methods to determine telomere length in tissues, single cells, and DNA preparations, each appropriate for different applications and reviewed extensively ${ }^{90,91}$. Quantitative polymerase chain reaction (qPCR) is amenable to large studies because it uses very small amounts of DNA and can be scaled up rapidly ${ }^{92,93}$. However, qPCR telomere assays generate a relative telomere length and are very sensitive to DNA extraction methods and storage ${ }^{94}$. These challenges have led to significant challenges in reproducing data in case-control or cohort studies of qPCR relative telomere length and phenotypes ${ }^{95,96}$. The telomere restriction fragment

Table 3. Features of robust telomere length association studies.

- Strong a priori hypothesis of why telomere biology might be important in disease of interest

- Comprehensive clinical phenotyping

- Accurately measured exposure of interest

- Large sample size with power calculations reported

- Collection of samples prior to disease onset

- Detailed information on how samples were collected, processed, and stored

- Telomere length measurement methods described in detail, especially if any adaptations to published methods

- Accurate and reproducible telomere length measurement

- Strong statistical justification of association findings 
method uses restriction enzymes to cut the subtelomeric ends of chromosomes in a DNA preparation and is most widely used in basic science laboratories, although a few groups use it in population-based studies ${ }^{90,91}$.

\section{Blood or buccal cell telomere length association studies}

This section highlights just a few key topics within the growing literature of telomere length association studies. For example, individuals of African ancestry have longer telomeres than those of European ancestry and thus ancestry should be accounted for in analyses ${ }^{97,98}$. Since self-reported ancestry can be quite variable, genomic approaches may be helpful in classifying cases and controls in order to appropriately adjust for ancestry.

There is also a growing understanding of associations between environmental exposures and telomere length. Smokers have shorter telomeres than non-smokers and thus it is important to adjust for smoking in association analyses ${ }^{99}$. Associations between prenatal exposures to smoking and air pollution as well as exposure to certain occupational chemicals have also been explored but with varying results ${ }^{100-105}$. In each of these studies, it is essential to precisely quantify the exposure of interest in addition to using a robust and reproducible telomere length measurement.

Early cancer-telomere length association studies suggested shorter telomeres as a cancer risk factor ${ }^{106,107}$ but studies of other cancers were not consistent ${ }^{108-112}$. Meta-analyses found that most studies with blood or buccal cell DNA collected prior to cancer diagnosis were null but that case-control studies were more likely to find associations ${ }^{113,114}$. Similarly, a direct comparison of prospectively and retrospectively collected DNA samples from patients with breast or colorectal cancer reported that telomere shortening occurred primarily after cancer diagnosis ${ }^{115}$. Many of these inconsistencies have been attributed to reverse causation bias due to the presence of cancer, underlying inflammation, or prior therapy at the time of sample collection ${ }^{113,116}$. Currently, the most consistent studies are those of longer telomeres in pre-diagnostic samples of patients with lung cancer and melanoma ${ }^{117-119}$. Interestingly, shorter leukocyte telomeres were associated with overall cancer mortality but not with cancer in a large prospective study of 64,637 individuals who developed 2,420 cancers $^{120}$.

There is a growing body of telomere length association studies and different aspects of mental health, including measures of perceived stress in caregivers, exposure to early life adversity, and in patients with schizophrenia, bipolar disorder, and depression $^{121-126}$. The biological mechanisms underlying these findings are unknown but current hypotheses include stress responses inducing oxidative stress, resulting in DNA damage and telomere shortening. Notably, abnormalities in brain development are present in patients with HH (cerebellar hypoplasia), RS (intracranial calcifications), and Coats plus (leukodystrophy and intracranial calcifications ${ }^{6,55}$. The only study to date of neuropsychiatric complications in DC found higher-than-expected occurrence of developmental delay and psychiatric disorders ${ }^{127}$.
Studies of DC/TBD patients by psychiatrists and neurobiologists constitute an unstudied area highly likely to generate important insights into telomere biology and brain development.

There is also a great deal of interest in using telomere length as a measure of biological age and even in modulating telomere length through lifestyle interventions. Numerous studies suggest associations between lifestyle, exercise, and telomere lengths ${ }^{128-133}$. However, a recent review suggests that telomere length in and of itself is not sufficient as a specific aging biomarker ${ }^{134}$.

Current data consistently report shorter leukocyte telomeres in individuals with atherosclerotic cardiovascular disease than in unaffected controls ${ }^{135-137}$. The biology underlying this association is thought to be related to chronic inflammation and oxidative stress coupled with aging of the vasculature. This prompted Aviv et al. to propose a model whereby age-dependent telomere shortening varies on the basis of the replicative needs of the specific tissue ${ }^{138,139}$. They hypothesize that skeletal muscle (a minimally replicative cell type) may represent telomere length closer to the time of birth and that the gap between skeletal muscle and leukocyte (a rapidly dividing cell type) telomere length attrition could serve to aid understanding of the associations between telomere length and human disease with each patient, in effect, serving as their own control. The first such study testing this hypothesis showed that increased attrition of telomeres in leukocytes was associated with atherosclerotic cardiovascular disease ${ }^{140}$.

Single-nucleotide polymorphisms, telomere biology genes, and disease

The advent of genome-wide association studies (GWAS) opened the door to understanding associations between common genetic variants (that is, greater than $1 \%$ minor allele frequency, SNPs) and human disease or phenotypes (Figure 5) (reviewed in 141). GWAS genotype hundreds of thousands of SNPs in thousands of cases and controls and use methods to fine-tune risk estimates through large-scale replication studies and polygenic risk score computation ${ }^{142}$.

Numerous GWAS of cancer etiology have identified variants in telomere biology genes as being associated with cancer risk or outcomes. SNPs in the TERT-CLPTMIL locus on chromosome 5 p15.33 are associated with multiple cancer types, including lung, pancreatic, breast, bladder, ovarian, prostate, and testicular germ cell cancers as well as glioma, melanoma, and non-melanoma skin cancers ${ }^{143-146}$. There are specific regions of this locus associated with different cancers, but these variants do not specifically encode deleterious coding alleles in TERT. They do, however, appear to be connected to telomere length through long-range regulation of this locus ${ }^{147}$.

SNPs in RTEL1 are associated with glioma in large GWAS of this rare brain cancer. The glioma-associated RTEL1 SNPs are intronic, but functional studies have not yet been completed to understand their potential functions ${ }^{148-152}$. These findings are intriguing because patients with DC or $\mathrm{HH}$ due to autosomal recessive RTEL1 mutations often have abnormal brain development 


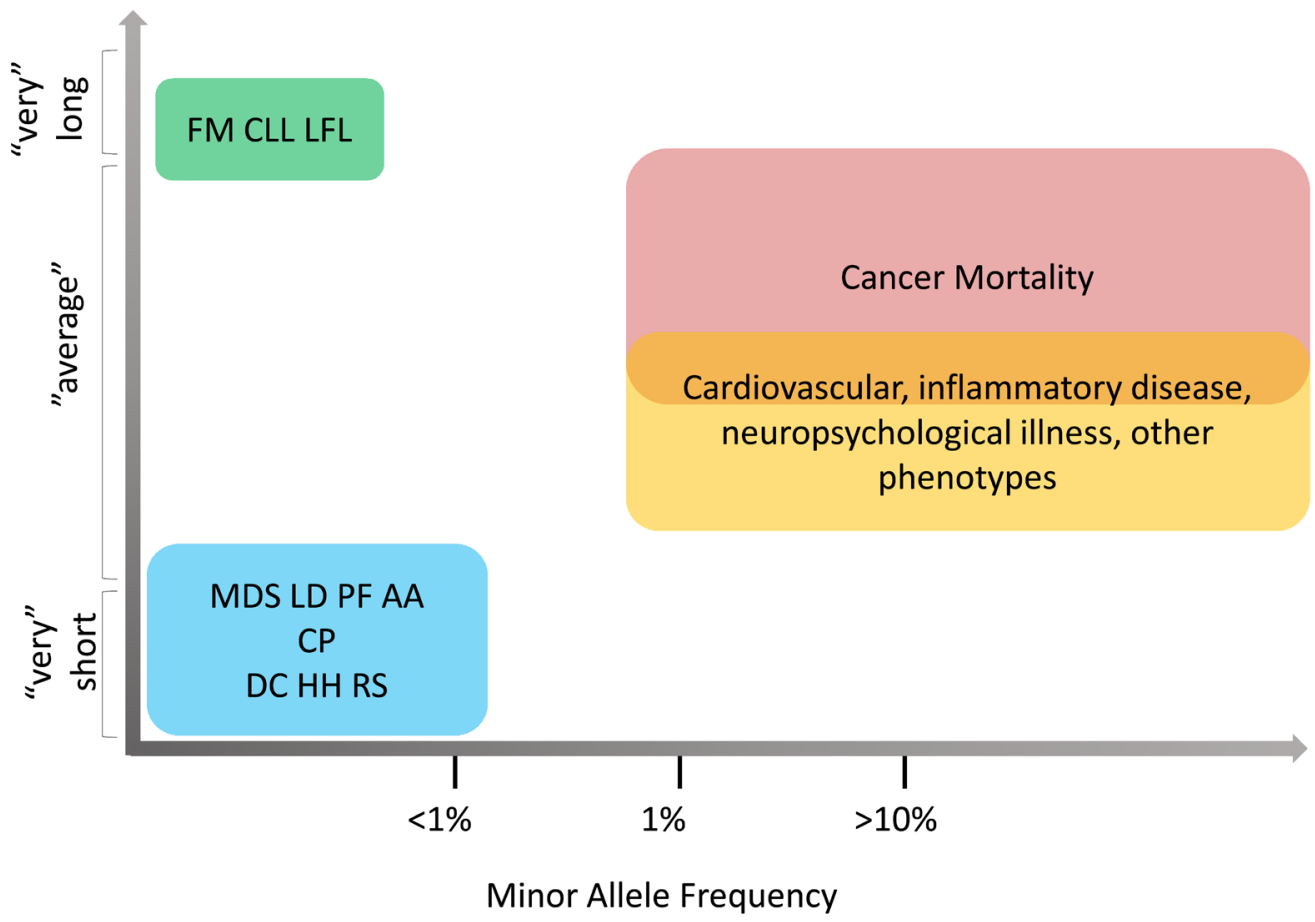

Figure 5. Relationship between telomere length, variant allele frequency, and human disease. The majority of genetic variants associated with common disease have a minor allele frequency (MAF) greater than $1 \%$ and telomeres in the "normal" range (that is, between the 1 st and 99th percentiles for age). In contrast, genetic variants associated with rare and more highly penetrant disease are rare with MAF often much less than $1 \%$ and the extremes of telomere length. AA, aplastic anemia; CLL, chronic lymphocytic leukemia; CP, Coats plus; DC, dyskeratosis congenita; FM, familial melanoma; HH, Hoyeraal Hreidarsson syndrome; LD, liver disease; LFL, Li-Fraumeni-like syndrome; MDS, myelodysplastic syndrome; PF, pulmonary fibrosis; RS, Revesz syndrome.

in the form of cerebellar hypoplasia ${ }^{35-37,153}$. Although the specific genetic loci are different, it is intriguing to speculate that there could be an important biological connection between these findings.

In addition to GWAS of cancer or other illnesses, several GWAS have been conducted to identify novel loci associated with telomere length. SNPs in known telomere biology genes, including TERT, OBFCl (encodes STN1), CTC1, TERC, $N A F 1$, and RTEL1, as well as genes not previously known to be associated with telomere biology have been discovered ${ }^{154-157}$. These studies illustrate the complexities of telomere length regulation by showing that even common genetic variants, and especially combinations of common genetic variants, are associated with telomere length in the general population.

The existence of telomere length GWAS in various populations set the stage for even larger studies using Mendelian randomization methods in which telomere length-associated SNPs serve as surrogates for telomere length ${ }^{158}$. One such study used nine telomere length-associated SNPs to create a telomere length surrogate score and found longer telomere length scores associated with lung adenocarcinoma but not the other cancers ${ }^{159}$. Renal cell carcinoma, one of the cancers with reproducible telomere length association data, was also studied using nine telomere length surrogate SNPs and it was found that genetically longer telomeres were associated with renal cell carcinoma $^{160}$.

In 2017, a Mendelian randomization study of 16 telomere length-associated SNPs from 103 GWAS with summary data on 35 cancers and 48 non-neoplastic diseases found that genetically longer telomeres associated with elevated risk of many cancers, including glioma, ovarian cancer, lung cancer, neuroblastoma, bladder, skin, testicular germ cell cancer and kidney cancer, and endometrial cancer ${ }^{161}$. That study also found an association between genetically shorter telomeres and the risk of interstitial lung disease, celiac disease, abdominal aortic aneurysm, and coronary heart disease but not of other inflammatory or psychiatric diseases ${ }^{161}$.

Although several studies suggest that telomere length is associated with depression, one study using Mendelian randomization and three SNPs-one each in TERT, TERC, and OBFCI-as surrogates for telomere length in 67,000 individuals did not find an association between depression and genetically shorter telomeres $^{162}$. These investigators used the same three SNPs to investigate genetically predicted telomere length and risk of 
ischemic heart disease ${ }^{163}$. They found small but statistically significant associations in a dataset of 60,837 ischemic heart disease cases compared with controls.

The studies briefly described above have generated a great deal of enthusiasm but are not without limitations. In many instances, qPCR was used to measure the telomere lengths in GWAS and this assay can be variable between studies. The sensitivity of the assay telomere length measurement and relatively small contributions of SNPs to telomere length should be considered in interpreting large-scale telomere length Mendelian randomization studies.

\section{The way forward}

The connections between telomere biology and human disease are complex and myriad and require a multi-disciplinary approach to truly understand the clinically relevant data, important basic science questions, and implications of epidemiologic analyses (Figure 1). As protectors of chromosome ends, telomeres are clearly integral to all aspects of cell biology. They are markers of biological aging and are regulated by a wide range of proteins.

Both very rare and very common germline genetic variants in telomere biology genes are associated with human disease, although the specific clinical phenotypes comprise a wideranging disease spectrum. Inheritance of telomere length inheritance and epigenetic regulation are also important aspects of telomere biology and should be incorporated into collaborative studies of rare and common telomere phenotypes. Additionally, optimization of telomere length measurement methods and improved understanding of environmental factors contributing to telomere biology will be essential in order to thoroughly understand these complexities. It is of the utmost importance for clinicians, epidemiologists, and basic scientists, all of whom study telomeres for a wide variety of different yet important reasons, to work together to build upon the expertise they each possess and incorporate that into improved understanding of telomere biology in human disease. This multi-disciplinary approach will enable the discovery of therapeutics and disease prevention modalities effective for patients with TBDs and for the general population.

\section{Abbreviations}

AML, acute myeloid leukemia; CLL, chronic lymphocytic leukemia; DC, dyskeratosis congenita; GWAS, genome-wide association study; $\mathrm{HH}$, Hoyeraal Hreidarsson syndrome; HNSCC, head and neck squamous cell carcinoma; MDS, myelodysplastic syndrome; qPCR, quantitative polymerase chain reaction; RS, Revesz syndrome; SNP, single-nucleotide polymorphism; TBD, telomere biology disorder.

\section{Competing interests}

The author declares that she has no competing interests.

\section{Grant information}

This work was supported by the intramural research program of the Division of Cancer Epidemiology and Genetics, National Cancer Institute, National Institutes of Health.

The funders had no role in study design, data collection and analysis, decision to publish, or preparation of the manuscript.

\section{Acknowledgments}

The author acknowledges the invaluable contributions of all patients and their families who have taught us so much about the complexities of telomere biology disorders in all their forms.
1. Zinsser F: Atropha cutis reticularis cum pigmentatione, dystrophia ungiumet leukoplakia oris. Ikongr Dermatol (Hyoto). 1906; 5: 219-223. Reference Source

2. Engman MF: A unique case of reticular pigmentation of the skin with atrophy. Arch Derm Syph. 1926; 13: 685-687. Reference Source

3. COLE HN, RAUSCHKOLB JE, TOOMEY J: DYSKERATOSIS CONGENITA WITH PIGMENTATION, DYSTROPHIA UNGUIS AND LEUKOKERATOSIS ORIS. Arch Dermatol. 1930; 21(1): 71-95.

Publisher Full Text

4. COSTELLO MJ, BUNCKE CM: Dyskeratosis congenita. AMA Arch Derm. 1956; 73(2): 123-32.

PubMed Abstract | Publisher Full Text

5. SORROW JM Jr, HITCH JM: DYSKERATOSIS CONGENITA. FIRST REPORT OF ITS OCCURRENCE IN A FEMALE AND A REVIEW OF THE LITERATURE. Arch Dermatol. 1963; 88(3): 340-7.

PubMed Abstract | Publisher Full Text

6. Bertuch AA: The molecular genetics of the telomere biology disorders. RNA Biol. 2016; 13(8): 696-706.

PubMed Abstract | Publisher Full Text | Free Full Text
7. Vulliamy TJ, Marrone A, Knight SW, et al.: Mutations in dyskeratosis congenita: their impact on telomere length and the diversity of clinical presentation. Blood 2006; 107(7): 2680-5.

PubMed Abstract | Publisher Full Text

8. Knight SW, Vulliamy T, Forni GL, et al:: Fine mapping of the dyskeratosis congenita locus in Xq28. J Med Genet. 1996; 33(12): 993-5. PubMed Abstract | Publisher Full Text | Free Full Text

9. Knight SW, Vulliamy TJ, Heiss NS, et al.: $1.4 \mathrm{Mb}$ candidate gene region for $X$ linked dyskeratosis congenita defined by combined haplotype and $X$ chromosome inactivation analysis. J Med Genet. 1998; 35(12): 993-6. PubMed Abstract | Publisher Full Text | Free Full Text

10. Knight SW, Heiss NS, Vulliamy TJ, et al: $\mathbf{X}$-linked dyskeratosis congenita is predominantly caused by missense mutations in the DKC1 gene. Am J Hum Genet. 1999; 65(1): 50-8. PubMed Abstract | Publisher Full Text | Free Full Text

11. $\mathrm{F}$ Mitchell JR, Wood E, Collins K: A telomerase component is defective in the human disease dyskeratosis congenita. Nature. 1999; 402(6761): 551-5. PubMed Abstract | Publisher Full Text | F1000 Recommendation

12. Baerlocher GM, Mak J, Tien T, et al:: Telomere length measurement by fluorescence in situ hybridization and flow cytometry: tips and pitfalls. 
Cytometry. 2002; 47(2): 89-99.

PubMed Abstract | Publisher Full Text

13. F Alter BP, Baerlocher GM, Savage SA, et al.: Very short telomere length by flow fluorescence in situ hybridization identifies patients with dyskeratosis congenita. Blood. 2007; 110(5): 1439-47.

PubMed Abstract | Publisher Full Text | Free Full Text | F1000 Recommendation

14. Alter BP, Rosenberg PS, Giri N, et al.: Telomere length is associated with disease severity and declines with age in dyskeratosis congenita. Haematologica. 2012; 97(3): 353-9.

PubMed Abstract | Publisher Full Text | Free Full Text

15. F Savage SA, Giri N, Baerlocher GM, et al:: TINF2, a component of the shelterin telomere protection complex, is mutated in dyskeratosis congenita. Am J Hum Genet. 2008; 82(2): 501-9.

PubMed Abstract | Publisher Full Text | Free Full Text | F1000 Recommendation

16. F Tsakiri KD, Cronkhite JT, Kuan PJ, et al:: Adult-onset pulmonary fibrosis caused by mutations in telomerase. Proc Natl Acad Sci U S A. 2007; 104(18): 7552-7.

PubMed Abstract | Publisher Full Text | Free Full Text | F1000 Recommendation

17. F Armanios MY, Chen JJ, Cogan JD, et al.: Telomerase mutations in families with idiopathic pulmonary fibrosis. N Engl J Med. 2007; 356(13): 1317-26. PubMed Abstract | Publisher Full Text | F1000 Recommendation

18. Yamaguchi H, Baerlocher GM, Lansdorp PM, et al:: Mutations of the human telomerase RNA gene (TERC) in aplastic anemia and myelodysplastic syndrome. Blood. 2003; 102(3): 916-8.

PubMed Abstract | Publisher Full Text

19. Aalbers AM, Kajigaya S, van den Heuvel-Eibrink MM, et al.: Human telomere disease due to disruption of the CCAAT box of the TERC promoter. Blood. 2012; 119(13): 3060-3.

PubMed Abstract | Publisher Full Text | Free Full Text

20. F Diaz de Leon A, Cronkhite JT, Katzenstein AL, et al:: Telomere lengths, pulmonary fibrosis and telomerase (TERT) mutations. PLoS One. 2010; 5(5): e10680.

PubMed Abstract | Publisher Full Text | Free Full Text | F1000 Recommendation

21. F Barbaro PM, Ziegler DS, Reddel RR: The wide-ranging clinical implications of the short telomere syndromes. Intern Med J. 2016; 46(4): 393-403. PubMed Abstract | Publisher Full Text | F1000 Recommendation

22. Savage SA, Bertuch AA: The genetics and clinical manifestations of telomere biology disorders. Genet Med. 2010; 12(12): 753-64.

PubMed Abstract | Publisher Full Text | Free Full Text

23. F Heiss NS, Knight SW, Vulliamy TJ, et al: X-linked dyskeratosis congenita is caused by mutations in a highly conserved gene with putative nucleolar functions. Nat Genet. 1998; 19(1): 32-8. PubMed Abstract | Publisher Full Text | F1000 Recommendation

24. F Vulliamy T, Marrone A, Goldman F, et al:: The RNA component of telomerase is mutated in autosomal dominant dyskeratosis congenita. Nature. 2001; 413(6854): 432-5.

PubMed Abstract | Publisher Full Text | F1000 Recommendation

25. Marrone A, Walne A, Tamary $\mathrm{H}$, et al.: Telomerase reverse-transcriptase homozygous mutations in autosomal recessive dyskeratosis congenita and Hoyeraal-Hreidarsson syndrome. Blood. 2007; 110(13): 4198-205. PubMed Abstract | Publisher Full Text | Free Full Text

26. F Horn S, Figl A, Rachakonda PS, et al:: TERT promoter mutations in familial and sporadic melanoma. Science. 2013; 339(6122): 959-61. PubMled Abstract | Publisher Full Text | F1000 Recommendation

27. Vulliamy TJ, Walne A, Baskaradas A, et al.: Mutations in the reverse transcriptase component of telomerase (TERT) in patients with bone marrow failure. Blood Cells Mol Dis. 2005; 34(3): 257-63. PubMed Abstract | Publisher Full Text

28. Walne AJ, Vulliamy T, Marrone A, et al:: Genetic heterogeneity in autosomal recessive dyskeratosis congenita with one subtype due to mutations in the telomerase-associated protein NOP10. Hum Mol Genet. 2007; 16(13): 1619-29. PubMed Abstract | Publisher Full Text | Free Full Text

29. Vulliamy T, Beswick R, Kirwan M, et al.: Mutations in the telomerase component NHP2 cause the premature ageing syndrome dyskeratosis congenita. Proc Nat/ Acad Sci U S A. 2008; 105(23): 8073-8. PubMed Abstract | Publisher Full Text | Free Full Text

30. $F$ Zhong $F$, Savage SA, Shkreli M, et al:: Disruption of telomerase trafficking by TCAB1 mutation causes dyskeratosis congenita. Genes Dev. 2011; 25(1): $11-6$

PubMed Abstract | Publisher Full Text | Free Full Text | F1000 Recommendation

31. F Venteicher AS, Abreu EB, Meng Z, et al:: A human telomerase holoenzyme protein required for Cajal body localization and telomere synthesis. Science. 2009; 323(5914): 644-8.

PubMed Abstract | Publisher Full Text | Free Full Text | F1000 Recommendation

32. F Anderson BH, Kasher PR, Mayer J, et al:: Mutations in CTC1, encoding conserved telomere maintenance component 1, cause Coats plus. Nat Genet. 2012; 44(3): 338-42

PubMed Abstract | Publisher Full Text | F1000 Recommendation
33. Polvi A, Linnankivi T, Kivelä T, et al.: Mutations in CTC1, encoding the CTS telomere maintenance complex component 1, cause cerebroretinal microangiopathy with calcifications and cysts. Am J Hum Genet. 2012; 90(3): $540-9$.

PubMed Abstract | Publisher Full Text | Free Full Text

34. Keller RB, Gagne KE, Usmani GN, et al:: CTC1 Mutations in a patient with dyskeratosis congenita. Pediatr Blood Cancer. 2012; 59(2): 311-4. PubMed Abstract | Publisher Full Text | Free Full Text

35. F Ballew BJ, Yeager M, Jacobs K, et al:: Germline mutations of regulator of telomere elongation helicase 1, RTEL1, in Dyskeratosis congenita. Hum Genet. 2013; 132(4): 473-80.

PubMed Abstract | Publisher Full Text | Free Full Text | F1000 Recommendation

36. Deng Z, Glousker G, Molczan A, et al:: Inherited mutations in the helicase RTEL1 cause telomere dysfunction and Hoyeraal-Hreidarsson syndrome. Proc Natl Acad Sci U S A. 2013; 110(36): E3408-16 PubMed Abstract | Publisher Full Text | Free Full Text

37. F Walne AJ, Vulliamy T, Kirwan M, et al.: Constitutional mutations in RTEL1 cause severe dyskeratosis congenita. Am J Hum Genet. 2013; 92(3): 448-53. PubMed Abstract | Publisher Full Text | Free Full Text | F1000 Recommendation

38. Kannengiesser C, Borie R, Ménard C, et al:: Heterozygous RTEL1 mutations are associated with familial pulmonary fibrosis. Eur Respir J. 2015; 46(2): 474-85. PubMed Abstract | Publisher Full Text

39. Cogan JD, Kropski JA, Zhao M, et al:: Rare variants in RTEL1 are associated with familial interstitial pneumonia. Am J Respir Crit Care Med. 2015; 191(6): 646-55. PubMed Abstract | Publisher Full Text | Free Full Text

40. Le Guen T, Jullien L, Touzot F, et al:: Human RTEL1 deficiency causes HoyeraalHreidarsson syndrome with short telomeres and genome instability. Hum $\mathrm{Mol}$ Genet. 2013; 22(16): 3239-49.

PubMed Abstract | Publisher Full Text

41. Aoude LG, Pritchard AL, Robles-Espinoza CD, et al:: Nonsense mutations in the shelterin complex genes ACD and TERF2IP in familial melanoma. $J$ Nat/ Cancer Inst. 2015; 107(2): pii: dju408

PubMed Abstract | Publisher Full Text | Free Full Text

42. F Stuart BD, Choi J, Zaidi S, et al.: Exome sequencing links mutations in PARN and RTEL1 with familial pulmonary fibrosis and telomere shortening. Nat Genet. 2015; 47(5): 512-7.

PubMed Abstract | Publisher Full Text | Free Full Text | F1000 Recommendation

43. Tummala $\mathrm{H}$, Walne A, Collopy L, et al:: $\operatorname{Poly}(\mathbf{A})$-specific ribonuclease deficiency impacts telomere biology and causes dyskeratosis congenita. $J$ Clin Invest. 2015; 125(5): 2151-60.

PubMed Abstract | Publisher Full Text | Free Full Text

44. Moon DH, Segal M, Boyraz B, et al:: Poly(A)-specific ribonuclease (PARN) mediates 3'-end maturation of the telomerase RNA component. Nat Genet. 2015; 47(12): 1482-8.

PubMed Abstract | Publisher Full Text | Free Full Text

45. Dhanraj S, Gunja SM, Deveau AP, et al:: Bone marrow failure and developmental delay caused by mutations in poly(A)-specific ribonuclease (PARN). J Med Genet. 2015; 52(11): 738-48.

PubMed Abstract | Publisher Full Text

46. Guo Y, Kartawinata M, Li J, et al.: Inherited bone marrow failure associated with germline mutation of $A C D$, the gene encoding telomere protein TPP1. Blood. 2014; 124(18): 2767-74.

PubMled Abstract | Publisher Full Text | Free Full Text

47. Speedy HE, Kinnersley B, Chubb D, et al:: Germ line mutations in shelterin complex genes are associated with familial chronic lymphocytic leukemia. Blood. 2016; 128(19): 2319-26.

PubMed Abstract | Publisher Full Text | Free Full Text

48. Kocak H, Ballew BJ, Bisht $\mathrm{K}$, et al:: Hoyeraal-Hreidarsson syndrome caused by a germline mutation in the TEL patch of the telomere protein TPP1. Genes Dev. 2014; 28(19): 2090-102.

PubMed Abstract | Publisher Full Text | Free Full Text

49. Simon AJ, Lev A, Zhang Y, et al:: Mutations in STN1 cause Coats plus syndrome and are associated with genomic and telomere defects. $J$ Exp Med. 2016; 213(8): 1429-40.

PubMed Abstract | Publisher Full Text | Free Full Text

50. Shi J, Yang XR, Ballew B, et al.: Rare missense variants in POT1 predispose to familial cutaneous malignant melanoma. Nat Genet. 2014; 46(5): 482-6. PubMed Abstract | Publisher Full Text | Free Full Text

51. Robles-Espinoza CD, Harland M, Ramsay AJ, et al.: POT1 loss-of-function variants predispose to familial melanoma. Nat Genet. 2014; 46(5): 478-81. PubMed Abstract | Publisher Full Text | Free Full Text

52. Calvete $\mathrm{O}$, Martinez $\mathrm{P}$, Garcia-Pavia $\mathrm{P}$, et al:: A mutation in the POT1 gene is responsible for cardiac angiosarcoma in TP53-negative Li-Fraumeni-like families. Nat Commun. 2015; 6: 8383.

PubMed Abstract | Publisher Full Text | Free Full Text

53. Takai H, Jenkinson E, Kabir S, et al.: A POT1 mutation implicates defective telomere end fill-in and telomere truncations in Coats plus. Genes Dev. 2016 30(7): 812-26.

PubMed Abstract | Publisher Full Text | Free Full Text

54. Stanley SE, Gable DL, Wagner CL, et al.: Loss-of-function mutations in the RNA biogenesis factor NAF1 predispose to pulmonary fibrosis-emphysema. $\mathrm{Sci}$ 
Transl Med. 2016; 8(351): 351ra107

PubMed Abstract | Publisher Full Text | Free Full Text

55. Savage SA: Dyskeratosis Congenita. in GeneReviews(R). R.A. Pagon, et al. Editors. 1993; Seattle (WA).

PubMed Abstract

56. Yaghmai R, Kimyai-Asadi A, Rostamiani K, et al.: Overlap of dyskeratosis congenita with the Hoyeraal-Hreidarsson syndrome. J Pediatr. 2000; 136(3): 390-3.

PubMed Abstract | Publisher Full Text

57. Kirwan M, Dokal I: Dyskeratosis congenita: a genetic disorder of many faces. Clin Genet. 2008; 73(2): 103-12.

PubMed Abstract | Publisher Full Text

58. Revesz T, Fletcher S, al-Gazali LI, et al.: Bilateral retinopathy, aplastic anaemia and central nervous system abnormalities: a new syndrome? J Med Genet. 1992; 29(9): 673-5.

PubMed Abstract | Publisher Full Text | Free Full Text

59. Savage SA: Connecting complex disorders through biology. Nat Genet. 2012; 44(3): 238-40.

PubMed Abstract | Publisher Full Tex

60. Crow YJ, McMenamin J, Haenggeli CA, et al:: Coats' plus: a progressive familial syndrome of bilateral Coats' disease, characteristic cerebral calcification, leukoencephalopathy, slow pre- and post-natal linear growth and defects of bone marrow and integument. Neuropediatrics. 2004; 35(1): 10-9. PublMed Abstract | Publisher Full Text

61. F Yamaguchi H, Calado RT, Ly H, et al:: Mutations in TERT, the gene for telomerase reverse transcriptase, in aplastic anemia. N Engl J Med. 2005; 352(14): 1413-24.

PubMed Abstract | Publisher Full Text | F1000 Recommendation

62. Ramsay AJ, Quesada V, Foronda M, et al:: POT1 mutations cause telomere dysfunction in chronic lymphocytic leukemia. Nat Genet. 2013; 45(5): 526-30. PubMed Abstract | Publisher Full Text

63. Véronèse $\mathrm{L}$, Tournilhac $\mathrm{O}$, Callanan $\mathrm{M}$, et al.: Telomeres and chromosomal instability in chronic lymphocytic leukemia. Leukemia. 2013; 27(2): 490-3. PubMed Abstract | Publisher Full Text

64. Lin TT, Norris K, Heppel NH, et al.: Telomere dysfunction accurately predicts clinical outcome in chronic lymphocytic leukaemia, even in patients with early stage disease. Br J Haematol. 2014; 167(2): 214-23.

PubMed Abstract | Publisher Full Text

65. Pepper C, Baird D, Fegan C: Telomere analysis to predict chronic lymphocytic leukemia outcome: a STELA test to change clinical practice? Expert Rev Hematol. 2014; 7(6): 701-3.

PubMed Abstract | Publisher Full Text

66. F Aviv A, Anderson JJ, Shay JW: Mutations, Cancer and the Telomere Length Paradox. Trends Cancer. 2017; 3(4): 253-8.

PubMed Abstract | Publisher Full Text | Free Full Text | F1000 Recommendation

67. F Feldser DM, Greider CW: Short telomeres limit tumor progression in vivo by inducing senescence. Cancer Cell. 2007; 11(5): 461-9.

PubMed Abstract | Publisher Full Text | Free Full Text | F1000 Recommendation

68. F Dagg RA, Pickett HA, Neumann AA, et al.: Extensive Proliferation of Human Cancer Cells with Ever-Shorter Telomeres. Cell Rep. 2017; 19(12): 2544-56. PubMed Abstract | Publisher Full Text | F1000 Recommendation

69. Reddel RR: Telomere maintenance mechanisms in cancer: clinical implications. Curr Pharm Des. 2014; 20(41): 6361-74. PubMed Abstract | Publisher Full Text | Free Full Text

70. $\mathrm{F}$ Tian $\mathrm{X}$, Doerig K, Park R, et al.: Evolution of telomere maintenance and tumour suppressor mechanisms across mammals. Philos Trans $R$ Soc Lond $B$ Biol Sci. 2018; 373(1741): pii: 20160443

PubMed Abstract | Publisher Full Text | Free Full Text | F1000 Recommendation

71. F Robinson NJ, Schiemann WP: Means to the ends: The role of telomeres and telomere processing machinery in metastasis. Biochim Biophys Acta. 2016; 1866(2): 320-9.

PubMed Abstract | Publisher Full Text | Free Full Text | F1000 Recommendation

72. Rousseau P, Autexier C: Telomere biology: Rationale for diagnostics and therapeutics in cancer. RNA Biol. 2015; 12(10): 1078-82.

PubMed Abstract | Publisher Full Text | Free Full Text

73. F Maciejowski J, de Lange T: Telomeres in cancer: tumour suppression and genome instability. Nat Rev Mol Cell Biol. 2017; 18(3): 175-86.

PubMed Abstract | Publisher Full Text | Free Full Text | F1000 Recommendation

74. Harley $\mathrm{CB}$, Futcher $\mathrm{AB}$, Greider $\mathrm{CW}$ : Telomeres shorten during ageing of human fibroblasts. Nature 1990; 345(6274): 458-60.

PubMed Abstract | Publisher Full Text

75. F Hemann MT, Strong MA, Hao LY, et al:: The shortest telomere, not average telomere length, is critical for cell viability and chromosome stability. Cell. 2001; 107(1): 67-77.

PubMed Abstract | Publisher Full Text | F1000 Recommendation

76. Dilley RL, Greenberg RA: ALTernative Telomere Maintenance and Cancer. Trends Cancer. 2015; 1(2): 145-56.

PubMed Abstract | Publisher Full Text | Free Full Text
77. Londoño-Vallejo JA: Telomere instability and cancer. Biochimie. 2008; 90(1): 73-82.

PubMed Abstract | Publisher Full Text

78. F Chiodi I, Mondello C: Telomere and telomerase stability in human disease and cancer. Front Biosci (Landmark Ed). 2016; 21: 203-24.

PubMed Abstract | Publisher Full Text | F1000 Recommendation

79. García-Cao M, Gonzalo S, Dean D, et al.: A role for the $\mathbf{R b}$ family of proteins in controlling telomere length. Nat Genet. 2002; 32(3): 415-9.

PubMed Abstract | Publisher Full Text

80. Pantic M, Zimmermann S, El Daly H, et al:: Telomere dysfunction and loss of p53 cooperate in defective mitotic segregation of chromosomes in cancer cells. Oncogene. 2006; 25(32): 4413-20.

PubMed Abstract | Publisher Full Text

81. Pópulo $\mathrm{H}$, Boaventura $\mathrm{P}$, Vinagre J, et al.: TERT promoter mutations in skin cancer: the effects of sun exposure and X-irradiation. $J$ Invest Dermatol. 2014 134(8): 2251-7.

PubMled Abstract | Publisher Full Tex

82. Vinagre J, Almeida A, Pópulo $\mathrm{H}$, et al:: Frequency of TERT promoter mutations in human cancers. Nat Commun. 2013: 4: 2185.

PubMed Abstract | Publisher Full Text

83. F Huang FW, Hodis $\mathrm{E}, \mathrm{Xu} \mathrm{MJ}$, et al:: Highly recurrent TERT promoter mutations in human melanoma. Science. 2013; 339(6122): 957-9. PubMed Abstract | Publisher Full Text | Free Full Text | F1000 Recommendation

84. F Alter BP, Giri N, Savage SA, et al.: Malignancies and survival patterns in the National Cancer Institute inherited bone marrow failure syndromes cohort study. Br J Haematol. 2010; 150(2): 179-88.

PubMed Abstract | Publisher Full Text | Free Full Text | F1000 Recommendation

85. Alter BP, Giri N, Savage SA, et al.: Cancer in dyskeratosis congenita. Blood. 2009; 113(26): 6549-57.

PubMed Abstract | Publisher Full Text | Free Full Text

86. Walne AJ, Dokal I: Dyskeratosis Congenita: a historical perspective. Mech Ageing Dev. 2008; 129(1-2): 48-59.

PubMed Abstract | Publisher Full Text

87. Alter BP, Giri N, Savage SA, et al.: Cancer in the National Cancer Institute inherited bone marrow failure syndrome cohort after fifteen years of follow-up. Haematologica. 2018; 103(1): 30-9. PubMed Abstract | Publisher Full Text | Free Full Text

88. Bodelon C, Savage SA, Gadalla SM: Telomeres in molecular epidemiology studies. Prog Mol Biol Transl Sci. 2014; 125: 113-31. PubMed Abstract | Publisher Full Text

89. Aviv A, Valdes AM, Spector TD: Human telomere biology: pitfalls of moving from the laboratory to epidemiology. Int J Epidemiol. 2006; 35(6): 1424-9. PubMed Abstract | Publisher Full Text

90. F Lai TP, Wright WE, Shay JW: Comparison of telomere length measurement methods. Philos Trans R Soc Lond B Biol Sci. 2018; 373(1741): pii: 20160451. PubMed Abstract | Publisher Full Text | Free Full Text | F1000 Recommendation

91. Aubert G, Hills M, Lansdorp PM: Telomere length measurement-caveats and a critical assessment of the available technologies and tools. Mutat Res. 2012; 730(1-2): 59-67.

PubMed Abstract | Publisher Full Text | Free Full Text

92. Cawthon RM: Telomere length measurement by a novel monochrome multiplex quantitative PCR method. Nucleic Acids Res. 2009; 37(3): e21. PubMed Abstract | Publisher Full Text | Free Full Text

93. Cawthon RM: Telomere measurement by quantitative PCR. Nucleic Acids Res. 2002; 30(10): e47.

PubMed Abstract | Publisher Full Text | Free Full Text

94. Dagnall $\mathrm{CL}$, Hicks B, Teshome $\mathrm{K}$, et al.: Effect of pre-analytic variables on the reproducibility of qPCR relative telomere length measurement. PLOS One. 2017; 12(9): e0184098.

PubMed Abstract | Publisher Full Text | Free Full Text

95. Martin-Ruiz CM, Baird D, Roger L, et al:: Reproducibility of telomere length assessment: an international collaborative study. Int J Epidemiol. 2015; 44(5): 1673-83.

PubMed Abstract | Publisher Full Text | Free Full Text

96. Gadalla SM, Khincha PP, Katki HA, et al:: The limitations of qPCR telomere length measurement in diagnosing dyskeratosis congenita. Mol Genet Genomic Med. 2016; 4(4): 475-9.

PubMed Abstract | Publisher Full Text | Free Full Text

97. F Hansen ME, Hunt SC, Stone RC, et al:: Shorter telomere length in Europeans than in Africans due to polygenetic adaptation. Hum Mol Genet. 2016; 25(11): 2324-30.

PubMed Abstract | Publisher Full Text | Free Full Text | F1000 Recommendation

98. Hunt SC, Chen W, Gardner JP, et al.: Leukocyte telomeres are longer in African Americans than in whites: the National Heart, Lung, and Blood Institute Family Heart Study and the Bogalusa Heart Study. Aging Cell. 2008; 7(4): 451-8. PubMed Abstract | Publisher Full Text | Free Full Text

99. F Astuti $\mathrm{Y}$, Wardhana $\mathrm{A}$, Watkins $\mathrm{J}$, et al:: Cigarette smoking and telomere length: A systematic review of $\mathbf{8 4}$ studies and meta-analysis. Environ Res. length: A system 2017 : $158: 480-9$.

2017; 158: 480-9.
PubMed Abstract | Publisher Full Text | Free Full Text | F1000 Recommendation 
100. Salihu HM, Pradhan A, King L, et al:: Impact of intrauterine tobacco exposure on fetal telomere length. Am J Obstet Gynecol. 2015; 212(2): 205.e1-8. PubMed Abstract | Publisher Full Text

101. F Ip P, Chung BH, Ho FK, et al:: Prenatal Tobacco Exposure Shortens Telomere Length in Children. Nicotine Tob Res. 2017; 19(1): 111-8. PubMed Abstract | Publisher Full Text | F1000 Recommendation

102. F Martens DS, Cox B, Janssen BG, et al.: Prenatal Air Pollution and Newborns' Predisposition to Accelerated Biological Aging. JAMA Pediatr. 2017; 171(12) 1160-7.

PubMed Abstract | Publisher Full Text | F1000 Recommendation

103. F Lu L, Johnman C, McGlynn L, et al:: Association between exposure to second-hand smoke and telomere length: cross-sectional study of 1303 nonsmokers. Int J Epidemiol. 2017; 46(6): 1978-84. PubMed Abstract | Publisher Full Text | F1000 Recommendation

104. Andreotti G, Hoppin JA, Hou L, et al.: Pesticide Use and Relative Leukocyte Telomere Length in the Agricultural Health Study. PLOS One. 2015; 10(7): e0133382

PubMed Abstract | Publisher Full Text | Free Full Text

105. Hou L, Andreotti G, Baccarelli AA, et al: Lifetime pesticide use and telomere shortening among male pesticide applicators in the Agricultural Health Study. Environ Health Perspect. 2013; 121(8): 919-24.

PubMed Abstract | Publisher Full Text | Free Full Text

106. Wu X, Amos $\mathrm{Cl}$, Zhu Y, et al.: Telomere dysfunction: a potential cance predisposition factor. $J$ Natl Cancer Inst. 2003; 95(16): 1211-8. PubMed Abstract | Publisher Full Text

107. Jang JS, Choi YY, Lee WK, et al:: Telomere length and the risk of lung cancer. Cancer Sci. 2008; 99(7): 1385-9. PubMed Abstract | Publisher Full Text

108. Mirabello L, Garcia-Closas M, Cawthon R, et al.: Leukocyte telomere length in a population-based case-control study of ovarian cancer: a pilot study. Cancer Causes Control. 2010; 21(1): 77-82. PubMed Abstract | Publisher Full Text | Free Full Text

109. Mirabello L, Huang WY, Wong JY, et al.: The association between leukocyte telomere length and cigarette smoking, dietary and physical variables, and risk of prostate cancer. Aging Cell. 2009; 8(4): 405-13. PubMed Abstract | Publisher Full Text | Free Full Text

110. Gramatges MM, Telli ML, Balise R, et al.: Longer relative telomere length in blood from women with sporadic and familial breast cancer compared with healthy controls. Cancer Epidemiol Biomarkers Prev. 2010; 19(4): 605-13. PubMed Abstract | Publisher Full Text

111. de Vivo I, Prescott J, Wong JY, et al.: A prospective study of relative telomere length and postmenopausal breast cancer risk. Cancer Epidemiol Biomarkers Prev. 2009; 18(4): 1152-6.

PubMed Abstract | Publisher Full Text | Free Full Text

112. Shen J, Terry MB, Gurvich I, et al:: Short telomere length and breast cancer risk: a study in sister sets. Cancer Res. 2007; 67(11): 5538-44. PubMed Abstract | Publisher Full Text

113. Wentzensen IM, Mirabello L, Pfeiffer RM, et al:: The association of telomere length and cancer: a meta-analysis. Cancer Epidemiol Biomarkers Prev. 2011; 20(6): $1238-50$

PubMed Abstract | Publisher Full Text | Free Full Text

114. Ma H, Zhou Z, Wei S, et al:: Shortened telomere length is associated with increased risk of cancer: a meta-analysis. PLoS One 2011; 6(6): e20466. PubMed Abstract | Publisher Full Text | Free Full Text

115. Pooley KA, Sandhu MS, Tyrer J, et al.: Telomere length in prospective and retrospective cancer case-control studies. Cancer Res. 2010; 70(8): 3170-6. PubMed Abstract | Publisher Full Text | Free Full Text

116. Zhu X, Han W, Xue W, et al.: The association between telomere length and cancer risk in population studies. Sci Rep. 2016; 6: 22243. PubMed Abstract | Publisher Full Text | Free Full Text

117. Seow WJ, Cawthon RM, Purdue MP, et al.: Telomere length in white blood cell DNA and lung cancer: a pooled analysis of three prospective cohorts. Cancer Res. 2014; 74(15): 4090-8.

PubMed Abstract | Publisher Full Text | Free Full Text

118. Sanchez-Espiridion B, Chen M, Chang JY, et al:: Telomere length in peripheral blood leukocytes and lung cancer risk: a large case-control study in Caucasians. Cancer Res. 2014; 74(9): 2476-86. PubMed Abstract | Publisher Full Text | Free Full Text

119. Rode L, Nordestgaard BG, Bojesen SE: Long telomeres and cancer risk among 95568 individuals from the general population. Int J Epidemiol. 2016; 45(5): $1634-43$.

PubMed Abstract | Publisher Full Text

120. Weischer M, Nordestgaard BG, Cawthon RM, et al.: Short telomere length, cancer survival, and cancer risk in 47102 individuals. J Natl Cancer Inst. 2013; 105(7): 459-68.

PubMed Abstract | Publisher Full Text

121. F Osler M, Bendix L, Rask L, et al.: Stressful life events and leucocyte telomere length: Do lifestyle factors, somatic and mental health, or low grade inflammation mediate this relationship? Results from a cohort of Danish men born in 1953. Brain Behav Immun. 2016; 58: 248-53.

PubMed Abstract | Publisher Full Text | F1000 Recommendation

122. Lindqvist D, Epel ES, Mellon SH, et al.: Psychiatric disorders and leukocyte telomere length: Underlying mechanisms linking mental illness with cellular aging. Neurosci Biobehav Rev. 2015; 55: 333-64.

PubMed Abstract | Publisher Full Text | Free Full Text

123. Shalev I, Entringer S, Wadhwa PD, et al:: Stress and telomere biology: a lifespan perspective. Psychoneuroendocrinology. 2013; 38(9): 1835-42.

PubMed Abstract | Publisher Full Text | Free Full Text

124. F Mathur MB, Epel E, Kind S, et al.: Perceived stress and telomere length: A systematic review, meta-analysis, and methodologic considerations for advancing the field. Brain Behav Immun. 2016; 54: 158-69.

PubMed Abstract | Publisher Full Text | Free Full Text | F1000 Recommendation

125. Hoen PW, de Jonge $\mathrm{P}, \mathrm{Na} \mathrm{BY}$, et al:: Depression and leukocyte telomere length in patients with coronary heart disease: data from the Heart and Soul Study. Psychosom Med. 2011; 73(7): 541-7.

PubMed Abstract | Publisher Full Text | Free Full Text

126. F Révész D, Verhoeven JE, Milaneschi Y, et al.: Depressive and anxiety disorders and short leukocyte telomere length: mediating effects of metabolic stress and lifestyle factors. Psychol Med. 2016; 46(11): 2337-49.

PubMed Abstract | Publisher Full Text | F1000 Recommendation

127. Rackley S, Pao M, Seratti GF, et al:: Neuropsychiatric conditions among patients with dyskeratosis congenita: a link with telomere biology? Psychosomatics. 2012; 53(3): 230-5. PubMed Abstract | Publisher Full Text | Free Full Text

128. Mundstock E, Zatti $\mathrm{H}$, Louzada FM, et al.: Effects of physical activity in telomere length: Systematic review and meta-analysis. Ageing Res Rev. 2015; 22: 72-80. PubMed Abstract | Publisher Full Tex

129. Ludlow AT, Ludlow LW, Roth SM: Do telomeres adapt to physiological stress? Exploring the effect of exercise on telomere length and telomere-related proteins. Biomed Res Int. 2013; 2013: 601368 PubMed Abstract | Publisher Full Text | Free Full Text

130. Mathur S, Ardestani A, Parker B, et al:: Telomere length and cardiorespiratory fitness in marathon runners. $J$ Investig Med. 2013; 61(3): 613-5. PubMed Abstract | Publisher Full Text

131. Østhus IB, Sgura A, Berardinelli $F$, et al:: Telomere length and long-term endurance exercise: does exercise training affect biological age? A pilot study. PLoS One. 2012; 7(12): e52769. PubMed Abstract | Publisher Full Text | Free Full Text

132. F García-Calzón S, Martínez-González MA, Razquin C, et al.: Mediterranean diet and telomere length in high cardiovascular risk subjects from the PREDIMED-NAVARRA study. Clin Nutr. 2016; 35(6): 1399-405. PublMed Abstract | Publisher Full Text | F1000 Recommendation

133. Sun $\mathrm{Q}$, Shi $\mathrm{L}$, Prescott $\mathrm{J}$, et al.: Healthy lifestyle and leukocyte telomere length in U.S. women. PLoS One. 2012; 7(5): e38374. PubMed Abstract | Publisher Full Text | Free Full Text

134. F Chilton W, O'Brien B, Charchar F: Telomeres, Aging and Exercise: Guilty by Association? Int J Mol Sci. 2017; 18(12): pii: E2573.

PubMed Abstract | Publisher Full Text | Free Full Text | F1000 Recommendation

135. F Haycock PC, Heydon EE, Kaptoge S, et al:: Leucocyte telomere length and risk of cardiovascular disease: systematic review and meta-analysis. BMJ. 2014; 349: g4227.

PubMed Abstract | Publisher Full Text | Free Full Text | F1000 Recommendation

136. D'Mello MJ, Ross SA, Briel M, et al:: Association between shortened leukocyte telomere length and cardiometabolic outcomes: systematic review and metaanalysis. Circ Cardiovasc Genet. 2015; 8(1): 82-90.

PubMed Abstract | Publisher Full Text

137. F Fitzpatrick AL, Kronmal RA, Gardner JP, et al:: Leukocyte telomere length and cardiovascular disease in the cardiovascular health study. Am J Epidemiol. 2007; 165(1): 14-21.

PubMed Abstract | Publisher Full Text | F1000 Recommendation

138. F Sabharwal S, Verhulst S, Guirguis G, et al:: Telomere length dynamics in early life: the blood-and-muscle model. FASEB J. 2018; 32(1): 529-34. PubMed Abstract | Publisher Full Text | Free Full Text | F1000 Recommendation

139. $\mathrm{F}$ Stone $\mathrm{RC}$, Horvath $\mathrm{K}$, Kark JD, et al.: Telomere Length and the CancerAtherosclerosis Trade-Off. PLOS Genet. 2016; 12(7): e1006144. PubMed Abstract | Publisher Full Text | Free Full Text | F1000 Recommendation

140. F Benetos A, Toupance S, Gautier S, et al.: Short Leukocyte Telomere Length Precedes Clinical Expression of Atherosclerosis: The Blood-and-Muscle Model. Circ Res. 2018; 122(4): 616-23. PubMed Abstract | Publisher Full Text | Free Full Text | F1000 Recommendation

141. F Sud A, Kinnersley B, Houlston RS: Genome-wide association studies of cancer: current insights and future perspectives. Nat Rev Cancer. 2017; 17(11): $692-704$

PubMed Abstract | Publisher Full Text | F1000 Recommendation

142. F Shi J, Park JH, Duan J, et al:: Winner's Curse Correction and Variable Thresholding Improve Performance of Polygenic Risk Modeling Based on Genome-Wide Association Study Summary-Level Data. PLoS Genet. 2016; 12(12): e1006493. PubMed Abstract | Publisher Full Text | Free Full Text | F1000 Recommendation

143. $\mathrm{F}$ Zhang $\mathrm{M}$, Wang Z, Obazee O, et al:: Three new pancreatic cancer susceptibility signals identified on chromosomes 1q32.1,5p15.33 and 8q24.21. 
Oncotarget. 2016; 7(41): 66328-43.

PubMed Abstract | Publisher Full Text | Free Full Text | F1000 Recommendation

144. Wang Z, Zhu B, Zhang M, et al.: Imputation and subset-based association analysis across different cancer types identifies multiple independent risk loci in the TERT-CLPTM1L region on chromosome 5p15.33. Hum Mol Genet. 2014; 23(24): 6616-33.

PubMed Abstract | Publisher Full Text | Free Full Text

145. Kote-Jarai Z, Saunders EJ, Leongamornlert DA, et al:: Fine-mapping identifies multiple prostate cancer risk loci at $5 \mathrm{p} 15$, one of which associates with TERT expression. Hum Mol Genet. 2013; 22(12): 2520-8. PubMed Abstract | Publisher Full Text | Free Full Text

146. Bojesen SE, Pooley KA, Johnatty SE, et al.: Multiple independent variants at the TERT locus are associated with telomere length and risks of breast and ovarian cancer. Nat Genet. 2013; 45(4): 371-84, 384e1-2. PubMed Abstract | Publisher Full Text | Free Full Text

147. F Fang J, Jia J, Makowski M, et al.: Functional characterization of a multicancer risk locus on chr5p15.33 reveals regulation of TERT by ZNF148. Nat Commun. 2017; 8: 15034

PubMed Abstract | Publisher Full Text | Free Full Text | F1000 Recommendation

148. Melin B, Dahlin AM, Andersson U, et al.: Known glioma risk loci are associated with glioma with a family history of brain tumours -- a case-control gene association study. Int J Cancer. 2013; 132(10): 2464-8. PubMed Abstract | Publisher Full Text | Free Full Text

149. Jin TB, Zhang JY, Li G, et al:: RTEL1 and TERT polymorphisms are associated with astrocytoma risk in the Chinese Han population. Tumour Biol. 2013; 34(6): 3659-66.

PubMed Abstract | Publisher Full Text

150. F Shete S, Hosking FJ, Robertson LB, et al:: Genome-wide association study identifies five susceptibility loci for glioma. Nat Genet. 2009; 41(8): 899-904. PubMed Abstract | Publisher Full Text | Free Full Text | F1000 Recommendation

151. F Wrensch M, Jenkins RB, Chang JS, et al:: Variants in the CDKN2B and RTEL1 regions are associated with high-grade glioma susceptibility. Nat Genet. 2009; 41(8): 905-8.

PubMed Abstract | Publisher Full Text | Free Full Text | F1000 Recommendation

152. F Delgado DA, Zhang C, Chen LS, et al:: Genome-wide association study of telomere length among South Asians identifies a second RTEL1 association signal. J Med Genet. 2018; 55(1): 64-71.

PubMed Abstract | Publisher Full Text | Free Full Text | F1000 Recommendation

153. Ballew $\mathrm{BJ}$, Joseph $\mathrm{V}$, De $\mathrm{S}$, et al:: A recessive founder mutation in regulator of telomere elongation helicase 1, RTEL1, underlies severe immunodeficiency and features of Hoyeraal Hreidarsson syndrome. PLoS Genet. 2013; 9(8): e1003695.

PubMed Abstract | Publisher Full Text | Free Full Text

154. Pooley KA, Bojesen SE, Weischer M, et al: A genome-wide association scan (GWAS) for mean telomere length within the COGS project: identified loci show little association with hormone-related cancer risk. Hum Mol Genet. 2013; 22(24): 5056-64.

PubMed Abstract | Publisher Full Text | Free Full Text

155. Mangino M, Hwang SJ, Spector TD, et al:: Genome-wide meta-analysis points to CTC1 and ZNF676 as genes regulating telomere homeostasis in humans. Hum Mol Genet. 2012; 21(24): 5385-94.

PubMed Abstract | Publisher Full Text | Free Full Text

156. $\mathrm{F}$ Mirabello $\mathrm{L}, \mathrm{Yu} \mathrm{K}, \mathrm{Kraft} \mathrm{P}$, et al:: The association of telomere length and genetic variation in telomere biology genes. Hum Mutat. 2010; 31(9): 1050-8. PubMed Abstract | Publisher Full Text | Free Full Text | F1000 Recommendation

157. Prescott J, Kraft P, Chasman DI, et al.: Genome-wide association study of relative telomere length. PLoS One. 2011; 6(5): e19635. PubMed Abstract | Publisher Full Text | Free Full Text

158. Emdin CA, Khera AV, Kathiresan S: Mendelian Randomization. JAMA. 2017; 318(19): 1925-6. PubMed Abstract | Publisher Full Text

159. Zhang C, Doherty JA, Burgess S, et al.: Genetic determinants of telomere length and risk of common cancers: a Mendelian randomization study. Hum Mol Genet. 2015; 24(18): 5356-66.

PubMed Abstract | Publisher Full Text | Free Full Text

160. Machiela MJ, Hofmann JN, Carreras-Torres R, et al.: Genetic Variants Related to Longer Telomere Length are Associated with Increased Risk of Renal Cell Carcinoma. Eur Urol. 2017; 72(5): 747-54. PubMed Abstract | Publisher Full Text | Free Full Text

161. F Telomeres Mendelian Randomization Collaboration, Haycock PC, Burgess S, et al.: Association Between Telomere Length and Risk of Cancer and NonNeoplastic Diseases: a Mendelian Randomization Study. JAMA Oncol. 2017 3(5): 636-651.

PubMed Abstract | Publisher Full Text | Free Full Text | F1000 Recommendation

162. Wium-Andersen MK, Ørsted DD, Rode L, et al:: Telomere length and depression: prospective cohort study and Mendelian randomisation study in 67306 individuals. Br J Psychiatry. 2017; 210(1): 31-8. PubMed Abstract | Publisher Full Text

163. F Scheller Madrid A, Rode L, Nordestgaard BG, et al:: Short Telomere Length and Ischemic Heart Disease: Observational and Genetic Studies in 290022 and Ischemic Heart Disease: Observational
Individuals. Clin Chem. 2016; 62(8): 1140-9. PubMed Abstract | Publisher Full Text | F1000 Recommendation 


\section{Open Peer Review}

\section{Current Peer Review Status:}

\section{Editorial Note on the Review Process}

Faculty Reviews are review articles written by the prestigious Members of Faculty Opinions. The articles are commissioned and peer reviewed before publication to ensure that the final, published version is comprehensive and accessible. The reviewers who approved the final version are listed with their names and affiliations.

\section{The reviewers who approved this article are:}

\section{Version 1}

\section{Fadi Charchar}

School of Applied and Biomedical Sciences, Faculty of Science and Technology, Federation University, Ballarat, Victoria, Australia

Competing Interests: No competing interests were disclosed.

\section{Steven E. Artandi}

1 Department of Medicine, Stanford University School of Medicine, Stanford, California, USA

2 Cancer Biology Program, Stanford University School of Medicine, Stanford, California, USA

3 Department of Biochemistry, Stanford University School of Medicine, Stanford, California, USA

Competing Interests: No competing interests were disclosed.

\section{Tracy Bryan}

Children's Medical Research Institute, University of Sydney, Sydney, New South Wales, Australia

Competing Interests: No competing interests were disclosed.

\section{Dirk Hockemeyer}

Department of Molecular and Cell Biology, University of California, Berkeley, Berkeley, California, USA

Competing Interests: No competing interests were disclosed. 
The benefits of publishing with F1000Research:

- Your article is published within days, with no editorial bias

- You can publish traditional articles, null/negative results, case reports, data notes and more

- The peer review process is transparent and collaborative

- Your article is indexed in PubMed after passing peer review

- Dedicated customer support at every stage

For pre-submission enquiries, contact research@f1000.com 